\title{
Avifaunal Diversity and Water Quality Analysis of an Inland Pond, Kondagai Village, Sivaganga District, South India
}

\author{
S. Muralikrishnan ${ }^{1 *}$ N. Arun Nagendran ${ }^{1}$, D. Pandiaraja ${ }^{1}$, Akhil Nair ${ }^{2}$ and T. Kubendran ${ }^{2}$ \\ ${ }^{1}$ National Centre of Excellence on Statistical and Mathematical Modeling on Bioresources \\ Management- MHRD, Thiagarajar College (Autonomous), Madurai-625 009, Tamil Nadu, India \\ ${ }^{2}$ High Altitude Regional Centre, Zoological Survey of India, Saproon,
} Solan - 721232, Himachal Pradesh, India

*Corresponding author

\begin{tabular}{|c|c|}
\hline & A B S T R A C T \\
\hline $\begin{array}{l}\text { Ke y w o r d s } \\
\text { Diversity, } \\
\text { Abiotic factors, } \\
\text { Konthagai, } \\
\text { parameters, } \\
\text { South India. }\end{array}$ & \multirow{3}{*}{$\begin{array}{l}\text { The key physical, chemical and biological parameters of one of the major habitat } \\
\text { for birds in the wetlands are known to influence flock of migratory and residen } \\
\text { species of birds. The present study deals with the interactions between these } \\
\text { abiotic factors and faunal diversity of pond in semiarid zone of Konthagai } \\
\text { Sivaganga district, Tamil Nadu. The study area was visited and surveyed twice in } \\
\text { a month. During each visit waterfowl census was carried out and water samples } \\
\text { were also collected to document changes in physico-chemical parameters and } \\
\text { microbial analysis over the seasons. The aggregation of birds in the area is mainly } \\
\text { related to the increase in migratory population of birds during winter. The } \\
\text { variations inland bird aggregations as well as physico-chemical factors are } \\
\text { discussed. }\end{array}$} \\
\hline Article Info & \\
\hline $\begin{array}{l}\text { Accepted: } \\
\text { 30 June } 2017 \\
\text { Available Online: } \\
\text { 10 July } 2017\end{array}$ & \\
\hline
\end{tabular}

\section{Introduction}

Avian community is an important component of an ecosystem. Birds are playing a major role in the environment as pollinators. Birds might live on this earth even if there were no human beings, but human beings cannot live without bird. Birds are an integral part of the whole system of life on this earth (Ali and Futehally, 2008). Birds are ideal bioindicators and useful models for studying a variety of environmental problems (Newton and Anim, 1995). They are often common denizens of the ecosystem and they have been considere $3 d$ as indicator species of inhabited areas (Blair, 1999). Many species of birds respond to small changes in habitat structure and composition, therefore they serve as good indicators of changes in the environment (Robert, 1932).

Birds are one of the best indicators of environmental quality of any ecosystem a number of environmental factors are known to influence the population of birds directly. Availability of food, detestability and capture, location of nesting sites, availability of nesting materials, presence of predators and competitors are the major factors influencing the foraging and breeding of birds and 
subsequently their population (Ali and Ripley, 1983). Out of more than 9000 bird's species of the world, the Indian subcontinent contains 1300 species or over $13 \%$ of the world's bird species (Grimmet et al., 2004).

Birds are the most apparent and familiar wildlife in wetlands. Wetlands are vital feeding and nesting grounds for waders, feeding areas for fish-eating birds and wintering grounds for migratory birds (Whigham et al., and Kusler et al., 1994). The relation between wetlands and birds are shaped by many factors. These include the availability, depth and quality of water, the availability of food and presence or absence of predators. Birds that use wetlands for breeding depend on the physical and biological attributes of the wetland. Birds have daily and seasonal dependencies on wetlands for food and other life-suborn systems. The value o0f a wetland to a specific bird species is affected by the presence of surface water or moist soils and the duration and timing of flooding (Mohapatra and Hussain, 1989). Wetlands are one of the most threatened habitats because of their vulnerability and attractiveness for their development (Hollis et al., 1988). In my field was undertaken to make a preliminary survey of physicochemical and biological parameters and birds on the Konthagai village ponds in relation to the associated water bodies with the objectives of analyzing the physicchemical and biological parameters of the ponds and to survey on avian fauna associated with the system.

Water birds and insects have long attracted the attention of the public and scientists because of their beauty, abundance, visibility and social behavior, as well as for their recreational and economic importance. Recently, water birds have become of interest as indicators of wetland quality and as parameters of restoration success and regional biodiversity (Kumar and Gupta, 2009). The present study aims to survey of birds, insects and plants to identify the consequences of direct and indirect human interferences.

\section{Materials and Methods}

\section{Study area}

Kondagai is a village under Tiruppuvanam Taluk in Sivaganga district of Tamil Nadu, India. It is located $37 \mathrm{KM}$ towards west from district head quarters of Sivaganga. It is $8 \mathrm{KM}$ from Tiruppuvanam. Kondagai village is encompassing two ponds via pond $\mathrm{A}$ and pond $\mathrm{B}$.

\section{Water analysis}

Water samples were collected from the experimental ponds during the study period. Depending upon the availability, water samples were collected from the pond with clean plastic bottles at $06.00 \mathrm{hrs}$ and brought to the laboratory for further analysis. Sampling and analytical procedures were done using American Public Health Association (APHA, 2005) method. Water pH was determined with the help of digital $\mathrm{pH}$ meter (Elico, India). Water temperature was measured during sampling with help of thermometer. Total Dissolved Solid (TDS), Conductivity, Salinity and Dissolved Oxygen (DO) were analyzed by using Water Analyzer Kit (Systronics Make; Model No. 371) also analyzed.

\section{Biological Parameters}

The collected water samples were subjected to various analyses such as enumeration of RTU's and Total Coli form (MPN).

Enumeration of bacterial load: The bacterial load of water sample was 
determined by spread plate technique after serial dilution of the sample.

Total Coli forms (MPN): The three basic tests (Presumptive, Confirmed, and Completed) were performed to detect coli form bacteria in water samples by using standard protocols described in Cappuccino and Sherman (1999).

\section{Entomological survey}

After netting a butterfly and dragonfly in sweeping or aerial net, the best way to kill it is by pinching its thorax (middle body segment) between thumb and forefinger. This technique takes some practice to learn the proper pressure, but it will quickly stun the specimen and prevent it from damaging itself. With its wings over its back, the specimen can then be slipped into an envelope or a paper triangle or envelope. Collected samples were brought to laboratory and identified under steriobinocular microscope using standard taxonomic literature. Samples were assigned to family and genus using keys for that particular group (Moore, 1890-1907; Talbot, 1939; Kehimkar, 2008; Kunte et al., 2017; Subramanian, 2005).

\section{Survey of birds}

The bird's survey was made during pre monsoon, monsoon, post monsoon and winter season at Kondagai, Sivagangai, south India. The birds counting from 06:30hrs to $11: 00 \mathrm{hrs}$ in the morning and $16: 00 \mathrm{hrs}$ to $18: 00 \mathrm{hrs}$ in the evening counted point count protocol method using Nikon (16*50 4.1) Action Zooming Binocular during the study period and photographic documentation was made.

Birds were identified by physical features by adopted Ali and Futehally (2008). Birds were identified up to species level and the diversity indices were calculated using PAST software.

\section{Results and Discussion}

\section{Physico-chemical parameters}

The results of physic-chemical parameters for the two ponds viz., Kondhagai pond A and B are given in table 1 . In all the two ponds the temperature ranged from $25-29^{\circ} \mathrm{C}$ during the study period. The results of $\mathrm{pH}$ revealed that the water in both ponds were in slightly alkaline in nature ranging from 7.32-9.04. Dissolved oxygen level was concurrently high in pond $\mathrm{B}$ than in pond $\mathrm{A}$ in the month of December 2015. Free carbon dioxide level was high in pond $\mathrm{A}$ in the month of December 2015.

\section{Enumeration of bacterial load}

The different bacterial colony forming units observed by spread plate technique were designated as Recognizable Taxonomic Units and were depicted in tables 2 and 3.

\section{Enumeration of total coli forms (MPN)}

The fermentation of lactose by coli form bacteria producing acid and gas was studied using the positive results obtained from the fermentation broth. It was confirmed by EMB agar pates. Determination if MPN (Most Probable Number) was done by comparing the results with the MPN index provided by Cappuccino and Sherman (1999). Results of gas production by coliform bacteria were depicted in figure 1.

A decreasing trend in MPN count was observed during the sampling periods. The MPN values are 1100, 290 and 150/100ml of the sample in pond $A$ in the month of October, December and February respectively. The MPN test results of both ponds were depicted in table 4 and 5. In EMB agar plate colonies with green metallic sheen were present in two ponds in the month of 
October 2015. There were dark blue centered, pink colour and purple with black centered colonies (Figs. 2a and b) present in all the three ponds in the month of December and February and they were considered as coliform bacteria. EMB plate cultures were subjected to Gram negative staining and rods were observed.

\section{Avian fauna}

During the study period the Kondagai village pond was surveyed and 3063 birds of 52 species belonging to 29 families were recorded. The list of birds observed in the study area is annexed in table 6 .

Ardeidae contributed the maximum species of seven (13\%). Columbidae and Cuculidae emerged as the next dominant family by 4 species (7.7\%). Three families were represented by 3 species $(5.8 \%)$ and the families are Corvidae, Ralidae and Accipitridae. Five families were represented by 2 species (3.8\%) and the families are Alcedinidae, Dicreridae, Nectariniidae, Muscicapidae and phalacrocoracidae. Rests of the families were represented by one species each.

The genus Streptopelia (3 species) was found to be the most dominant in the sanctuary followed by Corves, Dicrurus and Phalacrocorfax (2 species each). Maximum number of birds species present were categorized into resident 17 species belonging to 11 families followed by 18 species belonging to 11 families as common, 3 species belonging to 3 families as rare, 11 species belonging to 7 species as local migrant and 3 species belonging to 3 families as foreign migrant.

The maximum numbers of individual birds (1736) were recorded during monsoon season (October, 2015). Asian openbill (Anastomus oscitans) was the most abundant species 1053 $(34.4 \%)$ followed by common myna (Acsridotheres tristis) 275 (8.9\%), Cattle egret (Bubulcus ibis) $178 \quad$ (5.8\%) were recorded in the sanctuary surveyed.

The seasonal local migrant observed throughout the study period were Asian openbill (Anastomus oscitans) and Whitebrowed wagtail (Motacilla maderaspartensis). During the study periods 2 globally near threatened species were observed and the species are Darter (Anhinga melanogaster) and Oriental white ibis (Threskiornis melanocephalus).

Nine species recorded during the October 2015 survey were not seen during next two survey of the study area. Nearly 14 species recorded during the December 2015 and February 2016 survey were not seen in October 2015 survey.

Population change is usually displayed in the form of indices. Diversity indices were calculated by using PAST software and the values are reported in table $4 \mathrm{~b}$. The species richness index (Margalef) of birds in the study area was calculated which represented a high species richness (5.094) during October 2015 (Monsoon season) followed by (4.91) in December (Post monsoon season) and (4.188) in February (winter). The species richness index (Mehinick) was calculated and found to be high (1.211) in February 2016 (winter) followed by (1.18) in December (Post monsoon season) and (0.936) in October 2015 (Monsoon season).

The Shannon index showed highest diversity (3.054) during December followed by (2.553) in February and (1.912) in October. The month of October has the high Simpson index (0.6531) followed by 0.8851 and 0.9402 in February 2016 and December 2015 respectively. Maximum evenness index was 
observed December (0.6237) followed by February (0.4758) and October (0.1735).

\section{Survey of insects}

During the study period the Kondagai village pond was surveyed and 10 different species of Butterflies and 22 different species of dragonflies were recorded. Some of the butterflies and dragonflies are given Plate 1.

Wetlands are relatively safe areas which provide the birds with abundance of food and safe place for roosting, nesting and molting (Imaran Dar and Mithas, 2009). In Indian wetlands an approximately 318 species of birds were recorded out of which 193 species are fully dependent on wetlands (Vijayan, 1986).

The range, distribution and abundance of birds are closely linked to climatic factors which shape the relation between wetlands and birds. The factors include the availability of depth, quality of water, availability of food and shelter and the presence or absence of predators. Birds that use wetlands for breeding depend on the physical and biological attributes of the wetland. Any variation in any of these wetland features affects the distribution of birds (HU Nong Xing, 2005).

Any areas that possess $1 \%$ of its world population in a regular manner can be declared as an important bird's area (Rahmani, 2002). In any wetland ecosystem water quality and inhabiting organisms are interrelated. Here the routine physicochemical parameters of the water sample were analyzed. The $\mathrm{pH}$ of water plays an important role in the life of aquatic organisms because most of their metabolic activities are $\mathrm{pH}$ dependent (Kubendran and Ramesh 2016a\&b). According to King (1970), higher $\mathrm{pH}$ is normally associated with a high photosynthetic activity in water. The high $\mathrm{pH}$ in the month of November 2015 observed in the present study may be due to increased photosynthesis. Moreover, accumulation of dissolved salts, increased salinity due to high rate of evaporation in the month of February 2016.

Dissolved oxygen showed inverse relationship with water temperature. Maximum dissolved oxygen was observed during post monsoon season but minimum temperature was recorded. The results of the present study are in agreement with the studies of Ali et al., (1994) and Salam et al., (2000) who have observed the inverse relationship between dissolved oxygen and temperature.

Seasonal variation observed in dissolved oxygen content with higher values in rainy season could be due to increased aeration because of rainfall. Ayoade et al., (2006) reported that dissolved oxygen level in art Asejire Lake attained its peak in the rainy season. Temporal variations in aquatic systems can have direct and indirect effects on factors influencing nutrient fluxes (Thayer, 1971).

In this sanctuary the plankton population is found to be poor during winter due to increase in salinity but it was abundant during monsoon. The increased $\mathrm{CFU}$ in pond water may be due to the influence of temperature. Sahn indicated the doubling of bacterial growth rate with high temperature. MPN reflect the intensity and type of anthropogenic activities in the surrounding of sanctuary. According to $\mathrm{WHO}$ the possible presence of a single $E$. coli will determine the water as an unpotable. Thus the water available at the study area is not suitable for drinking purpose, even in small quantity. In the present study survey of the Kondagai pond revealed the presence of 3063 species of birds 
belonging to 29 families. In the study area only $26.92 \%$ of birds were migratory and the remaining was resident, common and rare. But in Bharathpur bird sanctuary $60 \%$ of birds are migratory (Vijayan, 1990).

In this sanctuary some colonially nesting large water birds that are known to breed in Indian heronries, for example, Little Cormorant, Great Cormorant, Darter, Little Egret, Grey Heron, Median Egret, Cattle Egret, Indian Pond-Heron, Night-Heron, Asian Openbill-Strok, Oriental White Ibis nest in Tamil Nadu. Little Egret and Cattle Egret are the some of the common species in the study site. This species are the resident and the food abundance of this species was high in most of the sites. It was found that rice fields and other agricultural habitats were used more by Cattle Egrets than other habitats (Lombardini et al., 2001).

During the study period two globally near threatened species (Vijayan, 1986) were recorded. The recorded species were Darter (Anhinga melanogaster) and Oriental White ibis (Threskiornis melanocephalus). Results of the survey and observations highlight the fact that avifauna here is decrease in number which; indicates unhealthy status of the sanctuary. In September 2015, the bird fauna is considerable increased by the arrival of several species of migratory birds. Towards the end of post monsoon, December 2015February 2016, most of the migratory birds started moving and also the water level started decreasing in the pond, which is the possible reason for the less number of birds. Various studies reported that water level and the bird abundance are inter-related (Colwell and Taft, 2000). Natural wetlands continue to decrease in area and throughout world (Czech and Parsons, 2002). Increasing anthropogenic activities are resulting into destruction of habitat and quality of water. In the present study, the abundance of native and migratory birds in the monsoon season may be due to the availability of food in the form of plants, Invertebrates and smaller vertebrates, herbivorous birds eat the fruits, tubers and leaves of wetland plants. It is also evident that the water temperature influences food production. Invertebrate production in the water column is ultimately depending on water temperature and the ability of a wetland to produce algae.

The decrease counts in the winter season are mainly due to the unavailability of food which includes the planktons and smaller animals. Further, the physico-chemical factors like $\mathrm{pH}$, salinity, dissolved oxygen and temperature, turbidity are also reported to be the determining factors, which may be conducive for native and migratory birds for feeding and breeding. A monsoon impact is the lowering of the temperature increasing the availability of water, which is followed by growth of vegetation. The rise in temperature and unavailability of vegetation during post monsoon and winter might have influenced the diversity of avian species. In the present study also, the relative density of avian species is lower in winter compared to monsoon and post monsoon. It may be due to high temperature and salinity and low dissolved oxygen content.

The seasonality of birds may be a reflection of their life style adaptation, particularly controlled by temperature. Further, unchecked poaching excessive grazing of littoral vegetation by domestic animals might have affected bird life by destroying habitats. The present investigation reveals that the impact of physic-chemical, biological parameters and the climatic changes after the monsoon highly affect the feeding, breeding and the population so that the avian community is failed to attain a better position to grow and establish for the continuation of the race. 
Table.1 Physico- chemical parameters of Konthaigai pond A and B during the sampling period from October 2015 to February 2016

\begin{tabular}{|c|c|c|c|c|c|c|c|}
\hline S.No & Parameters & Oct 2015 & Dec 2015 & Feb 2016 & Oct 2015 & Dec 2015 & Feb 2016 \\
\hline 2 & Total solids $(\mathrm{g} / \mathrm{L})$ & 1.1 & 0.4 & 0.4 & 1.3 & 1.4 & 0.96 \\
\hline 3 & Total Dissolved Solids (g/L) & 1 & 03 & 0.2 & 0.6 & 0.7 & 0.20 \\
\hline 6 & Electrical Conductivity(U/S) & 297 & 237 & 428 & 144 & 173 & 446 \\
\hline 7 & Salinity (ppt) & 0.16 & 0.14 & 0.25 & 0.09 & 0.09 & 0.27 \\
\hline 8 & $\mathrm{pH}$ & 7.8 & 8.41 & 7.32 & 7.9 & 8.05 & 9.04 \\
\hline 9 & Dissolved Oxygen (mg/L) & 9.9 & 11.01 & 8.16 & 9.1 & 8.56 & 7.8 \\
\hline $\mathbf{1 0}$ & Free Carbondioxide (ppm) & 6 & 3 & 3 & 4 & 5 & 4 \\
\hline
\end{tabular}


Table.2 Bacterial load of the Kondhagai pond A and B during the sampling period from October 2015 to February 2016

\begin{tabular}{|c|c|c|c|c|c|c|}
\hline & \multicolumn{2}{|c|}{ October - 2015 } & \multicolumn{2}{c|}{ December - 2015 } & \multicolumn{2}{c|}{ February - 2016 } \\
\hline RTU & Pond A & Pond B & Pond A & Pond B & Pond A & Pond B \\
\hline $\mathbf{1}$ & 25 & 2 & 35 & - & 7 & - \\
\hline $\mathbf{2}$ & 2 & 2 & 2 & - & - & - \\
\hline $\mathbf{3}$ & 6 & 2 & - & - & - & - \\
\hline $\mathbf{4}$ & 2 & 1 & 32 & - & - & - \\
\hline $\mathbf{5}$ & - & 12 & 26 & - & - & - \\
\hline $\mathbf{6}$ & - & 2 & 2 & 3 & - & - \\
\hline $\mathbf{8}$ & - & 3 & 4 & - & 3 & - \\
\hline $\mathbf{9}$ & - & 1 & 2 & - & 4 & - \\
\hline $\mathbf{1 0}$ & - & 3 & - & 38 & 22 & - \\
\hline $\mathbf{1 1}$ & - & - & - & 17 & - & - \\
\hline $\mathbf{1 2}$ & - & - & - & 2 & & - \\
\hline $\mathbf{1 3}$ & - & - & - & - & - & - \\
\end{tabular}

Table.3 Enumeration of Total coli forms (MPN) in Kondhagai pond A and B during the sampling period from October 2015 to February 2016

\begin{tabular}{|c|c|c|c|c|c|c|c|}
\hline \multirow{2}{*}{ S.No } & \multirow{2}{*}{ Test } & \multicolumn{2}{|c|}{ October - 2015} & \multicolumn{2}{|c|}{ December - 2015} & \multicolumn{2}{|c|}{ February - 2016} \\
\hline & & Pond A & Pond B & Pond A & Pond B & Pond A & Pond B \\
\hline 1 & $\mathrm{MPN} / 100 \mathrm{ml}$ & 1100 & 1100 & 290 & 460 & 150 & 210 \\
\hline 2 & EMB Plate & $\begin{array}{l}\text { Green Metalic } \\
\text { sheen \& Pink } \\
\text { colonies }\end{array}$ & $\begin{array}{l}\text { Green Metalic } \\
\text { sheen \& Pink } \\
\text { colonies }\end{array}$ & $\begin{array}{l}\text { Dark blue centered, } \\
\text { Pink \& Dark brown } \\
\text { colonies }\end{array}$ & $\begin{array}{l}\text { Dark blue } \\
\text { centered, Pink } \\
\text { \& Dark brown } \\
\text { colonies }\end{array}$ & $\begin{array}{l}\text { Dark blue } \\
\text { centered, Pink } \\
\text { \& Dark brown } \\
\text { colonies }\end{array}$ & $\begin{array}{l}\text { Dark blue } \\
\text { centered, Pink \& } \\
\text { Dark brown } \\
\text { colonies }\end{array}$ \\
\hline 3 & Gram Stain & Rod & Rod & Rod & Rod & Rod & Rod \\
\hline
\end{tabular}


Table.4 Birds recorded in Kondhagai pond A and B during the sampling period from October 2015 to February 2016

\begin{tabular}{|c|c|c|c|c|c|c|c|c|c|}
\hline \multirow{3}{*}{$\begin{array}{l}\text { S. } \\
\text { No }\end{array}$} & \multirow{3}{*}{ Family } & \multirow{3}{*}{$\begin{array}{c}\text { Scientific Name of the } \\
\text { Birds }\end{array}$} & \multirow{3}{*}{ Common Name } & \multicolumn{6}{|c|}{ Number of Individual } \\
\hline & & & & \multicolumn{2}{|c|}{ October - 2015} & \multicolumn{2}{|c|}{$\begin{array}{l}\text { December } \\
2015\end{array}$} & \multicolumn{2}{|c|}{ February - 2016} \\
\hline & & & & $\mathbf{A}$ & B & $\mathbf{A}$ & B & $\mathbf{A}$ & B \\
\hline 1 & \multirow{3}{*}{ Acciptitridae } & Accipiter badius & Shikra & 0 & 0 & 0 & 0 & 2 & 2 \\
\hline 2 & & Milvus migrans & Black Kite & 0 & 0 & 0 & 0 & 3 & 3 \\
\hline 3 & & Pandion haliaetus & Ospray & 0 & 0 & 0 & 0 & 1 & 1 \\
\hline 4 & \multirow[b]{2}{*}{ Alcedinidae } & Alcedo atthis & Common Kingfisher & 4 & 4 & 11 & 11 & 0 & 0 \\
\hline 5 & & Halcyon smyrenis & $\begin{array}{l}\text { White-Breasted } \\
\text { Kingfisher }\end{array}$ & 1 & 1 & 8 & 8 & 7 & 7 \\
\hline 6 & Anatidae & Anas crecca & Common Teal & 4 & 4 & 29 & 29 & 0 & 0 \\
\hline 7 & Anhingidae & Anhinga melanogaster & Darter & 26 & 26 & 0 & 0 & 0 & 0 \\
\hline 8 & Apodidae & Tachymarptis melba & Asian Palm-Swift & 25 & 25 & 41 & 41 & 35 & 35 \\
\hline 9 & \multirow{7}{*}{ Ardeidae } & Ardea cinerea & Gray Heron & 1 & 1 & 0 & 0 & 0 & 0 \\
\hline 10 & & Ardeola grayii & Indian Pond-Heron & 20 & 20 & 30 & 30 & 35 & 35 \\
\hline 11 & & Bubulcus ibis & Cattle Dgret & 18 & 18 & 60 & 60 & 100 & 100 \\
\hline 12 & & Casmerodius albus & Great Egret & 3 & 3 & 0 & 0 & 0 & 0 \\
\hline 13 & & Egretta garzetta & Little Egret & 20 & 20 & 10 & 10 & 6 & 6 \\
\hline 14 & & Egretta intermedia & Median Egret & 50 & 50 & 0 & 0 & 0 & 0 \\
\hline 15 & & Nycticorax nycticorax & Night Heron & 40 & 40 & 0 & 0 & 0 & 0 \\
\hline 16 & Artamidae & Artamus fuscus & Ashy Woodswallow & 0 & 0 & 35 & 35 & 0 & 0 \\
\hline 17 & Charadriidae & Vanellus indicus & Red-Watted Lapwing & 0 & 0 & 3 & 3 & 0 & 0 \\
\hline 18 & Ciconiidae & Anastomus oscitans & Asian Openbill Stork & 1000 & 1000 & 52 & 52 & 1 & 1 \\
\hline 19 & \multirow{4}{*}{ Columbidae } & Columba livia & Rock Pigeon & 16 & 16 & 0 & 0 & 0 & 0 \\
\hline 20 & & Streptopelis chinensis & Spotted Dove & 3 & 3 & 20 & 20 & 0 & 0 \\
\hline 21 & & Streptopelia decaocto & Eurasian Collard Dove & 7 & 7 & 12 & 12 & 0 & 0 \\
\hline 22 & & Streptopelia sengalensis & Laughing Dove & 2 & 2 & 1 & 1 & 0 & 0 \\
\hline 23 & \multirow{2}{*}{ Corvidae } & Corves macrorhynchos & Jungle Crow & 4 & 4 & 30 & 30 & 13 & 13 \\
\hline 24 & & Corves splendens & House Crow & 40 & 40 & 40 & 40 & 60 & 60 \\
\hline
\end{tabular}




\begin{tabular}{|c|c|c|c|c|c|c|c|c|c|}
\hline 25 & & Dentrocitta vagabunda & Rufous Treepie & 6 & 6 & 12 & 12 & 5 & 5 \\
\hline 26 & \multirow{4}{*}{ Cuculidae } & Centropes sinensis & Greater Coucal & 3 & 3 & 1 & 1 & 7 & 7 \\
\hline 27 & & Clamator jacobinus & Pied Cuckoo & 1 & 1 & 0 & 0 & 0 & 0 \\
\hline 28 & & Cuculus poliocephalus & Lesser Cuckoo & 1 & 1 & 1 & 1 & 1 & 1 \\
\hline 29 & & Eydynamys scolopecea & Asian Koel & 1 & 1 & 0 & 0 & 3 & 3 \\
\hline 30 & \multirow{2}{*}{ Dicrurudae } & Dicrurus leucophaeus & Ashy Drongo & 7 & 7 & 7 & 7 & 0 & 0 \\
\hline 31 & & Dicrurus macrocercus & Black Drongo & 20 & 20 & 30 & 30 & 0 & 0 \\
\hline 32 & Monarchidae & Terpsiphone paradise & Asian Paradisetrepie & 0 & 0 & 0 & 0 & 12 & 12 \\
\hline 33 & Motacillidae & Motacilla maderaspatensis & White-Browed Wagtail & 10 & 10 & 3 & 3 & 26 & 26 \\
\hline 34 & \multirow{2}{*}{ Muscicapidae } & Luscinia brunnea & Indian Blue Robin & 0 & 0 & 7 & 7 & 0 & 0 \\
\hline 35 & & Saxicoloides fulicata & Indian Robin & 2 & 2 & 6 & 6 & 2 & 2 \\
\hline 36 & \multirow{2}{*}{ Nectariniidae } & Nectarinia asiatica & Purple Sunbird & 2 & 2 & 0 & 0 & 9 & 9 \\
\hline 37 & & Nectarinia zeylonica & Purple Rumped Sunbird & 0 & 0 & 0 & 0 & 4 & 4 \\
\hline 38 & Oriolidae & Oriolus oriolus & Golden Oriole & 0 & 0 & 0 & 0 & 5 & 5 \\
\hline 39 & Passeridae & Passer domesticus & House Sparrow & 40 & 40 & 36 & 36 & 12 & 12 \\
\hline 40 & \multirow{2}{*}{$\begin{array}{l}\text { Phalacrocoracida } \\
\text { e }\end{array}$} & Phalacrocorax carbo & Great Cormorant & 5 & 5 & 0 & 0 & 0 & 0 \\
\hline 41 & & Phalacrocorax niger & Little Cormorant & 150 & 150 & 4 & 4 & 1 & 1 \\
\hline 42 & Phasianidae & Pavo cristaus & Indian Peafowl & 20 & 20 & 70 & 70 & 15 & 15 \\
\hline 43 & Picidae & Dinopium benghalense & $\begin{array}{l}\text { Black-Rumped } \\
\text { Flameback }\end{array}$ & 1 & 1 & 1 & 1 & 0 & 0 \\
\hline 44 & Podicipedidae & Tachybaptus ruficollis & Little Grebe & 0 & 0 & 9 & 9 & 0 & 0 \\
\hline 45 & Psittacidae & Psittcula krameri & Rose-Ringed Parakeet & 20 & 20 & 40 & 40 & 25 & 25 \\
\hline 46 & Pycnonotidae & Pycnonotus cafer & Ret-Vented Bulbul & 6 & 6 & 0 & 0 & 0 & 0 \\
\hline 47 & \multirow{3}{*}{ Rallidae } & Amaurornis phoenicurus & $\begin{array}{l}\text { White-Breasted } \\
\text { Waterhen }\end{array}$ & 7 & 7 & 12 & 12 & 0 & 0 \\
\hline 48 & & Fulica atra & Common Coot & 0 & 0 & 21 & 21 & 0 & 0 \\
\hline 49 & & Gallinula chloropus & Common Moorhen & 0 & 0 & 3 & 3 & 0 & 0 \\
\hline 50 & Scolopacidae & Actitis hypoleucos & Common Sandpiper & 0 & 0 & 0 & 0 & 7 & 7 \\
\hline 51 & Sturnidae & Acridotheres tristis & Common Myna & 75 & 75 & 100 & 100 & 100 & 100 \\
\hline 52 & Threskiornithidae & $\begin{array}{l}\text { Threskiornis } \\
\text { melanocephalus }\end{array}$ & Oriental White Ibis & 75 & 75 & 85 & 85 & 0 & 0 \\
\hline
\end{tabular}


Table.5 Diversity indices of birds at Kondagai pond A and B during the sampling period from October 2015 to February 2016

\begin{tabular}{|c|c|c|c|c|c|c|c|}
\hline S.No & Particulars & Pond A & Pond B & Pond A & Pond B & Pond A & Pond B \\
\hline 1 & Taxa & 39 & 39 & 34 & 34 & 27 & 27 \\
\hline 2 & Individuals & 1736 & 1736 & 830 & 830 & 497 & 497 \\
\hline 4 & Simpson & 0.6531 & 0.6531 & 0.9402 & 0.9402 & 0.8851 & 0.8851 \\
\hline 5 & Shannon & 1.912 & 1.912 & 3.054 & 3.054 & 2.553 & 2.553 \\
\hline 8 & Margalef & 5.094 & 5.094 & 4.91 & 4.91 & 4.188 & 4.188 \\
\hline
\end{tabular}


Fig.1 Gas produced by coli form bacteria in Kondagai pond A and B during the sampling period from October 2015 to February 2016

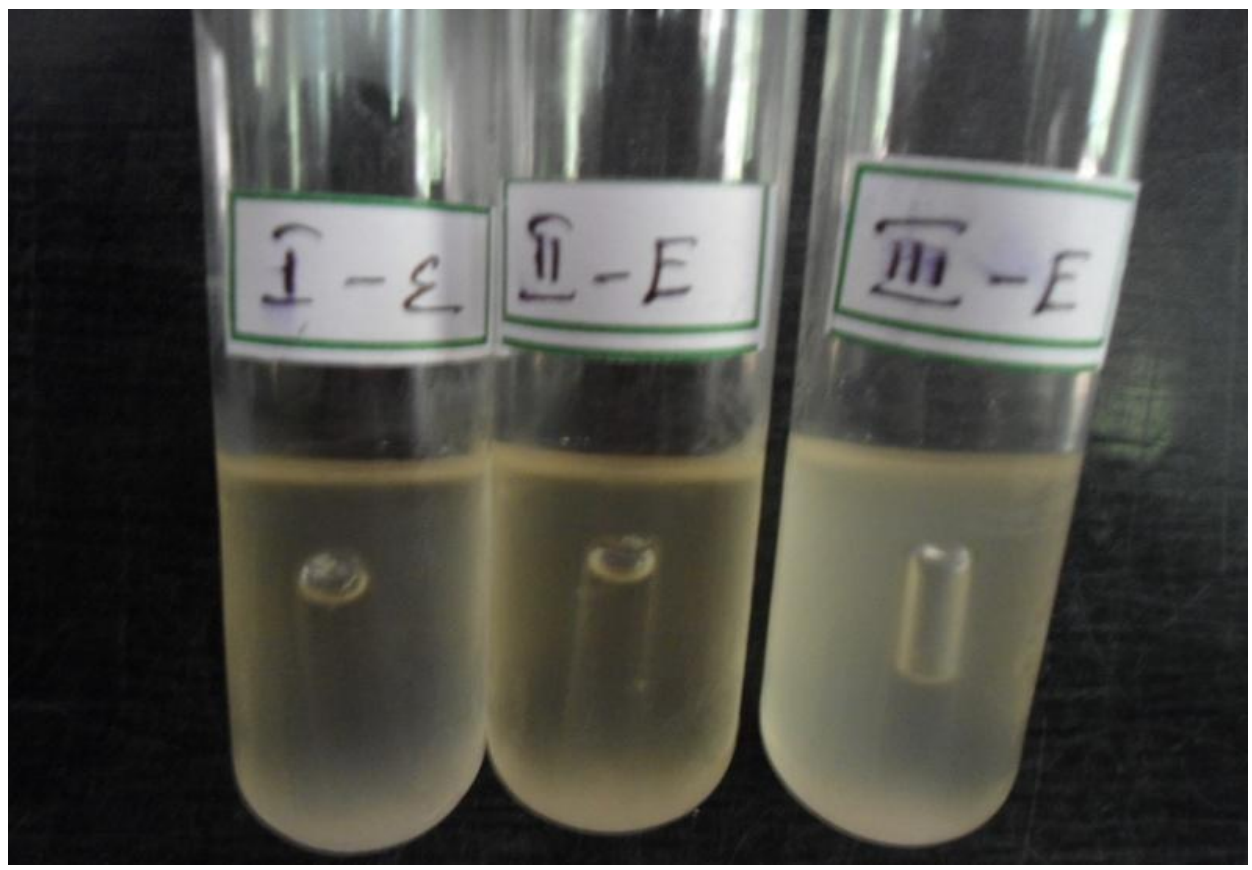

Fig.2a\&b Colonies with green metallic sheen and blue centers in Kondagai pond A and B during the sampling period from October 2015 to February 2016

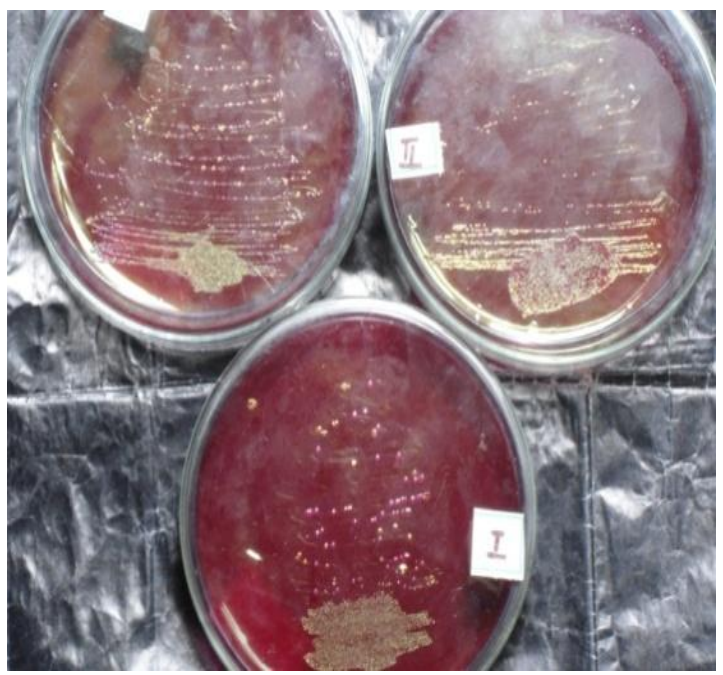

A

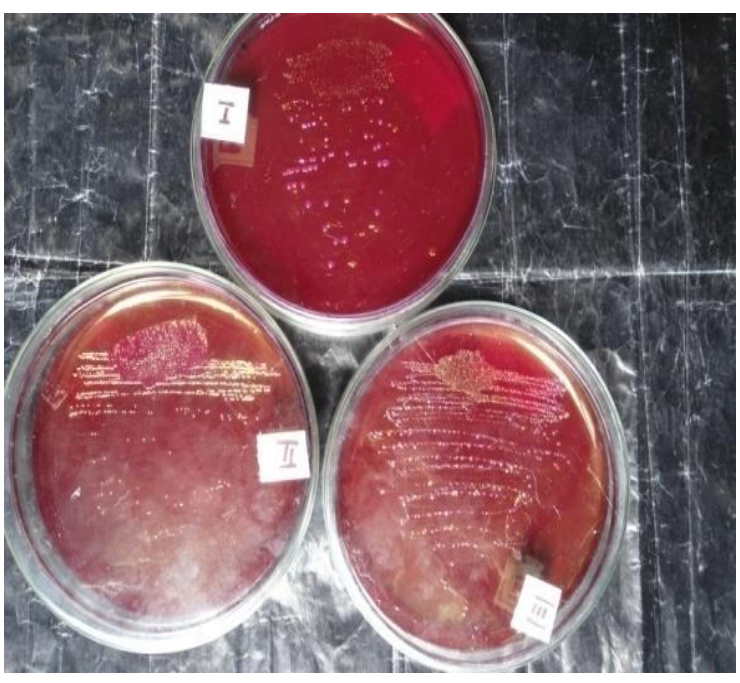

B 
Int.J.Curr.Microbiol.App.Sci (2017) 6(7): 4437-4452
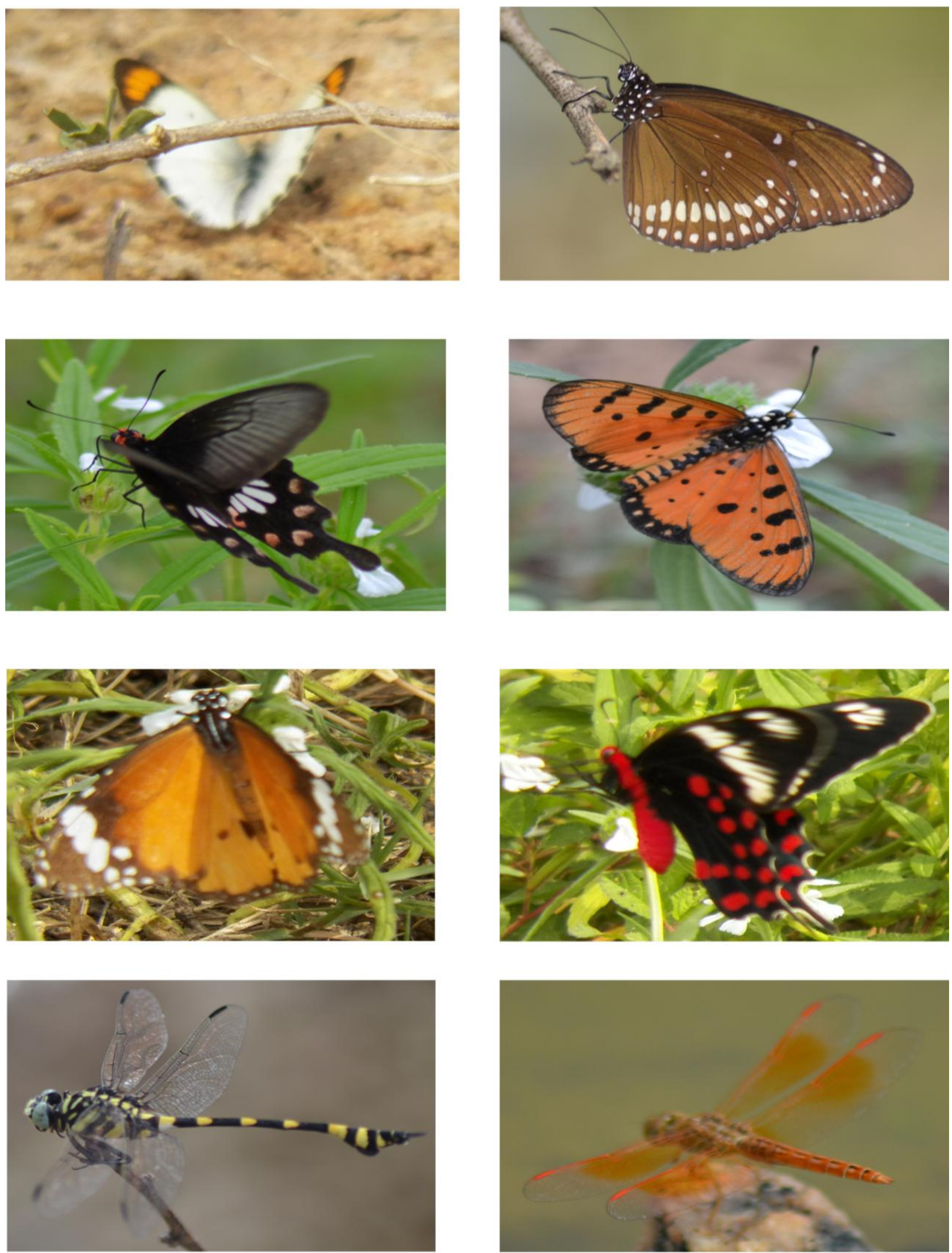

Plate 1: Some Butterfles and Draganflies recorded in Kondhagai pond A\&B during the study period 
In North America's Prairie Pothole region, models have projected an increase in drought with a $3{ }^{\circ} \mathrm{C}$ regional temperature increase and varying changes in precipitation, leading to large losses of wetlands and to declines in the populations of waterfowl breeding there (Johnson et al., 2005; Krishnan et al 2017). One review of 300 migrant bird species found that $84 \%$ face some threat from climate change, almost half because of changes in water regime and this was equal to the summed threats due to all other anthropogenic causes (Robinson et al., 1982). The data on birds was subjected to diversity analysis using PAST and various diversity measures were calculated. The Shannon index of the samples ranged from 65 to 94 . High Shannon value indicating low diversity was observed in the month of December 2015. In concurrence with this, the Shannon value was high in the same month.

The sanctuary was selected as one of important birds area due to large breeding colony of avifauna. About 5000 birds belonging to 250 species used to visit this sanctuary during breeding seasons and more than 250 nests of open bills and 100 of oriental ibis were normally found during this season. But only 52 species of birds were observed during the study period reveal the degradation of the habitat due to cattle grazing, non availability of nesting trees, predators, poor rainfall and so on which shrinks the bird's population. Restoration of habitat by native trees, restriction of grazing and improving water storage capacity of the ponds will enhance the population and diversity of the birds and the ecosystem.

In conclusion, in the present study, to evaluate the physico-chemical and biological characteristics of pond water and to assess the relative density, abundance of native and migratory avian species in pond A and B was carried out during the period of October 2015 to February 2016. In both ponds, the physicochemical characteristics and MPN count were in accordance with general trend. The observation on the bird's population revealed that the presence of 3063 birds belonging to 29 families. In the study area only $26.92 \%$ of birds were migratory and the remaining ones were resident, common and rare. During the study period two globally near threatened species viz Anhinga melanogaster (Darter) and Threskiornis melanocephalus (Oriental White ibis) were recorded. In the present study, the abundance of native and migratory birds in the monsoon season may be due to the availability of food in the form of plants, Invertebrates and smaller vertebrates, herbivorous birds eat the fruits, tubers and leaves of wetland plants. It is also evident that the water temperature influences food production. Invertebrate production in the water column is ultimately depending on water temperature and the ability of a wetland to produce algae. The present investigation reveals that the impact of physic-chemical, biological parameters and the climatic changes after the monsoon highly affect the feeding, breeding and the population so that the avian community is failed to attain a better position to grow and establish for the continuation of the race.

\section{Acknowledgments}

The authors gratefully acknowledge MHRD, Government of India, New Delhi for providing financial support and establishment of National Centre of Excellence in Statistical and Mathematical Modeling on Bioresources Management in Thiagarajar College, Madurai. Akhil Nair and T. Kubendran thank to Dr. Kailash Chandra, Director and Dr. Avtar Kaur Sidhu, Scientist 'D' and Officer in- Charge, HARC, ZSI for identification of butterflies during study. 


\section{References}

American Public Health Association. 2005. Standard methods for the examination of water and wastewater. American Public Health Association, Water Environment Federation.

Ali, M., A. and Hussian, M.Z. 1994. Effect of seasonal variations on physic-chemical parameters of Zaidi Fish farm, Punjab Univ. J. Zool., 9: 53-58.

Ali, S and Futehally. 2008. About Indian Birds. Wisdom Tree, New Delhi. (vi)

Ali, S. and Ripely, S.D. 19836. A Pictorial guide to the birds of the Indian subcontinent. Bombay Natural History Society, Mumbai, 19(1): 43-47.

Ayodae, A.A., Fagade, S.O. and Abebisi, A.A. 2006. Dynamics of limnological features of two man-made lakes in relation to fish production, African Journal of Biotechnology, 510: 10131021.

Blair, R.B. 1999. Birds and butterflies along an urban gradient. Surrogate taxa for assessing biodiversity. Ecol. Appl., 9: 164-170.

Cappucino, J.G. and Sherman, N. 1999. Microbiological A laboratory manual. $4^{\text {th }}$ edition, Wesley.

Colwell, M.A. and Taft, O.W. 2000. Water bird communities in managed wetlands of varying water depth. Water birds, 23: 1121-1133.

Czech, H.A. and Parsons, K.C. 2002. Agricultural wetlands and water birds: A Review. Water Birds, 25: 56-65.

Grimmet, R., Inskip, T. and Islam, M. Z. 2004. Birds of Northern India. Christopher Helm A and C. Bleak Publisher. Ltd, London.

Hollis, G.E., Holand, M.M. and Larson, J.S. 1988. Wise use of wetlands. Nature and Resources, 24(1): 2-13.

HU Hong- Xing. 2005. Biodiversity of Winter water birds in Hubei, China. 14:
422-428.

Imran A Dar And Mithas A Dar. 2009. Seasonal Variations of Avifauna of Shallabug Wetland, Kashmir, Journal of Wetlands Ecology, 2: 20-34.

Johnson, W.C., Millett, B.V., Gilmanov, T., Voldseth, R.A., Guntenspergen, G.R. and Naugle, D.E. 2005. Vulnerability of northern prairie wetlands to climate; change. BioScience, 55: 863-872.

Kehimkar, I. 2008. The Book of Indian Butterflies. BNHS, Oxford University, Delhi Press. Pp. 499.

King, D.L. 1970. The role on carbon I eutrophication. J. Water pollution control federation, 42: 2035-2015.

Krishnan, S.M. N Arun Nagendran and D Pandiaraja. 2017. Survey of birds in Chitrangudi and Kanjirankulam village ponds in relation to vegetation: an avian paradise of south India. Journal of Entomology and Zoology Studies. 5(1): 407-412.

Kubendran T. Ramesh M. 2016. Composition and distribution of aquatic insect communities in relation to water quality in two freshwater streams of southern Western Ghats, India. J. Entomol. Zool. Stud., 4(5): 689-695.

Kubendran T. Ramesh M. 2016. Monitoring of adult aquatic insect activities and ecological role in the riparian zone of streams in the Western Ghats, India. IRA-Int. J. App. Sci. 4(3): 460-470.

Kumar, P. Gupta, S.K. 2009. Diversity and Abundance of Wetland Birds around Kurukshetra, India, Nepal Journals online. 7:212-217

Kunte, K.J., Roy, S. Kalesh, R. and Kodandaramaiah, U. 2017. Butterflies of Peninsular India. Pp1-254.

Kusler, J.A., Mitsch., W.J. and Larson, J.S. 1994. Wetlands. Sci. Amer., 270: 6470.

Lombardini, K., Bennetts, R.E. and Tourneg, C. 2001. Foraging success and foraging 
habitat used by Cattle Egrets and Little Egrets in Camargue, France. Condor, 103: 38-44.

Mohapatra, K.K. and Hussain, S.A. 1989. Avifauna of Chilka lake. In:S.N. Patro(ed) Chilka, The pride of our Wetland heritage. Orissa Envt.Soc., Bhuvaneswar.

Moore, F. 1890-1907. Lepidoptera Indica. Vols I-VII Lovell and Reeve London.

Newton, L. and Anim, M. 1995. The contribution of some recent research on birds to Ecological understanding. J. Anim. Ecol., 64: 675-696.

Rahmani, A. 2002. Asian Water-bird census: Final report, India. Bombay Natural History Society, Bombay.

Robert, T.S. 1932. The birds of Minnesota. Minneapolis, University of Minnesota.

Robinson, R.A., Learmonth, J.A., Hutson, A.M., Macleod, C.D., Sparks, T.H., Sahn, M.A., Banna, A.A., and Shehatea, A.M. 1982. Occurrence of Vibrio parahaemolticus in sea water around Alexandria, Eygpt.Can. J. Microbial. 278: 1261-1264.

Salam, A., Ali, M., khan, B.A. and Rizvi, S.
2000. Seasonal changes in physicochemical parameters of river Chenab Muzaffar Garh, Punjab, Pakistan. J. Bio. Sci., 4: 299-301.

Subramanian, K.A. 2005. Dragonflies and Damselflies in Peninsular India, Field guide. Pp.1-35

Talbot, G. 1939. The Fauna of British India including Ceylon and Burma (Butterflies) Pp 600.

Thayer, G. 1971. Phytoplankton Production and the distribution of Nutrients in a shallow, Unstrartified estuarine System near Beaufort. NC. Chesapeake Science, 12: 240-253.

Vijayan, V.S. 1986. On conserving the birdfauna of Indian wetlands in Proceeding of Indian Academy of Sciences (Suppl),91-101.

Vijayan, V.S. 1990. Keoladeo National Park ecology study (1980-1990). An overview. BNHS., Mumbai.

Whighman, T.D., Bykyjova. and Hejny, M. (Eds). 1993. Wetlands of the world Inventory, Ecology and Management. Kulwer Academic Publishers Dordredht, Netherland.

\section{How to cite this article:}

Muralikrishnan, S., N. Arun Nagendran, D. Pandiaraja, Akhil Nair and Kubendran, T. 2017. Avifaunal Diversity and Water Quality Analysis of an Inland Pond, Kondagai Village, Sivaganga District, South India. Int.J.Curr.Microbiol.App.Sci. 6(7): 4437-4452. doi: https://doi.org/10.20546/ijcmas.2017.607.463 